\title{
PENDAMPINGAN PEMBINAAN BACA TULIS AL-QURAN, IBADAH DAN MORAL REMAJA DESA DALEMAN DUSUN BATES KEDUNGDUNG SAMPANG
}

\author{
Oleh: \\ Ali Wafa ${ }^{1}$, Ach. Rafiuddin $^{2}$, Lukman ${ }^{3}$, Jali $^{4}$, Imamah $^{5}$, \& Musyarrofah $^{6}$ \\ IAI Nazhatut Thullab Sampang1 \\ Mahasiswa Prodi PAI IAI Nazhatut Thullab Sampang2,3,4 \\ Email: awafa9851@gmail.com
}

\begin{abstract}
Abstrak:
Pengabdian kepada masyarakat sebagai Tri Dharma Perguruan Tinggi, harus dilakukan secara kontino demi sebagai penerapan sebuah ilmu pengetahuan yang dimiliki serta sebagai wujud kepadulian kepada masalah-masalah atau fenomena sosial yang terjadi pada masyarakat umum. Dengan adanya kegiatan pengabdian ini diharapkan menjadi solusi atau mampu mengatasi masalah-masalah atau fenomena sosial yang terjadi pada masyarakat tersebut. Tanpa kepedulian dari kelompok atau masyarakat akademik, maka sulit untuk menumbuhkan sumber daya manusia yang berdaya dan berpengetahuan luas. Salah satu pendampingan pembinaan yang dilakukan adalah, 1) sosialisasi pencegahan covid 10;2) pembinaan baca tulis al-Quran; 3) pembinaan ibadah; dan 4) pembinaan moral atau akhlak anak/remaja. Harapan dari kegiatan pengabdian menjadi solusi dan pengatehuan praktis bagi masyarakat, anak-anak dan remaja.
\end{abstract}

Kata Kunci: Pembinaan Baca Tulis Al-Quran, Ibadah, Moral Remaja

\section{PENDAHULUAN}

Pengabdian kepada masyarakat bagi perguruan tinggi merupakan suatu kewajiban sejajar dengan pendidikan/pengajaran dan penelitian, dalam istilah lain dikatakan sebagai Tri Dharma Perguruan Tinggi yang mencakup aspek perguruan, pendidikan dan pengabdian masyarakat. ${ }^{1}$ Dalam sebuah ilmu pengetahuan, terdapat 2 kerangka yang keduanya tidak dapat dipisahkan. Yakni kerangka teoritis dan kerangka praktis. Dalam kerangka teoritis, pelajar dalam hal ini mahasiswa, menyerap ilmu dari teori-teori yang telah ada, memahami, menelaah kemudian menuangkan kembali dalam gagasan yang baru atau mengembangkan teori yang telah ada. Sedangkan dalam kerangka peraktis mahasiswa dapat menyerap ilmu pengetahuan melalui teori atau lapangan, kemudian

\footnotetext{
${ }^{1}$ Sudin,kuliah pengabdian masyarakat perguruan tinggi islam,journal of UIN Sunan Kalijaga diakses tanggal 21 juli 2020 jam 21:41
} 
menuangkannya dalam bentuk peraktek. Dalam kerangka ini, Ilmu pengetahuan ditransfer ke masyarakat luas melalui praktek. Mahasiswa, sebagai pelajar pada tingkat Pendidikan perguruan tinggi, memiliki tugas untuk menguasai dua kerangka Ilmu pengetahuan tersebut.

Pengabdian kepada masyarakat merupakan usaha yang dilakukan oleh seseorang baik individu ataupun kelompok untuk membantu peningkatan taraf hidup atau permasalahan yang terjadi dalam masyarakat. Dengan demikian mahasiswa dapat mengetahui bagaimana keadaan dan situasi di sebuah lapangan, Jika biasanya pengabdian masyarakat (PKM) dilakukan secara berkelompok dan ditempatkan secara acak namun tidak pada tahun ini kuliah pengabdian masyarakat dilakukan dirumah masing-masing. Disebabkan keadaan yang masih belum stabil, maka kegiatan PKM kali ini berbeda dengan kegiatan PKM yang sebelumnya.

Pengabdian kepada Masyarakat (PKM) dengan pendekatan tematik ini merupakan salah satu program dari Tri Dharma Perguruan Tinggi yang bertujuan untuk membangun kepekaan dan sinergi antara civitas akademika perguruan tinggi dengan masyarakat. Sebagai bagian dari masyarakat, baik dosen ataupun mahasiswa dituntut untuk mampu bersosialisasi dengan masyarakat, peka terhadap masalah yang terjadi dalam masyarakat dan mampu memberikan solusi atas permasalahan sesuai bidang keilmuan yang ditekuni dan keahlian yang dimiliki. Kegiatan PKM ini tidak hanya mengasah kemampuan teknis kompetensi (hard skill), namun juga soft skill yang dimiliki oleh dosen dan mahasiswa. Dosen dan Mahasiswa yang tergabung dalam pengabdian kolaboratif in diharapkan mampu membantu memecahkan masalah yang dihadapi di lingkungan wilayah pelaksanaan PKM.

Penyelenggaraan PKM seyogyanya dapat menjangkau tiga sasaran utama. Pertama, sebagai sarana pembelajaran bagi para mahasiswa untuk mengimplementasikan ilmu yang sudah didapatkan selama perkuliahan sesuai dengan bidangnya masing-masing. Kedua, PKM dapat memberikan nilai tambah dalam rangka meningkatkan kualitas kehidupan masyarakat. Ketiga, PKM 
merupakan media untuk membangun kemitraan antar lembaga perguruan tinggi yang bersangkutan dengan masyarakat, termasuk di dalamnya sebagai upaya untuk membangun citra kelembagaan.

Adapun yang menjadi alasan yang paling mendasar atas pemilihan desa dampingan tersebut adalah maraknya penyebaran COVID 19 sehingga kami memilih desa yang saat ini kami tempati sebagai tempat objek dampingan, untuk senantiasa membantu pemerintah dan pihak kesehatan dalam mengurangi korban virus tersebut. Demi meningkatkan kualitas dalam segi pendidikan merupakan salah satu tujuan dari setiap kegiatan yang dilakukan, dengan mengadakan pembinaan untuk masyarakat dusun Bates dalam memberdayakan dan mengembangkan masyarakat melalui pendampingan dalam rangka mewujudkan masyarakat yang lebih baik. Dan target utama dalam kegiatan kali ini adalah anakanak dan semua masyarakat yang membutuhkan yang berada di dusun Bates.

Salah satu dampingan pembinaan yang dlakukan adalah peningkatan dalam membaca Al-Quran Dan pembinaan ibadah dan kegiatan lain yang dirasa perlu untuk dilakukan di dusun tersebut. Selain itu melihat pengertian dari pengabdian, alasan kami memilih desa Daleman tepatnya di Dusun Bates karena ingin lebih meningkatkan hal yang berhubungan dengan keadaan desa tersebut mengingat sistem saat ini sudah sampai pada titik 4.0 yang semua ranahnya berhubungan dengan teknologi agar masyarakat desa tidak menyalahgunakan sistem tersebut.

Sedangkan tujuan khusus dari adanya PKM ini meliputi: 1) Menjadikan civitas akademika mampu belajar bersama masyarakat dalam menemukan dan memecahkan masalah. 2) Meningkatkan kesadaran civitas akademika terhadap kehidupan masyarakat. 3) Merealisasikan fungsi civitas akademika sebagai agent of change dan agent of social control. 4) Memberikan alternatif solusi bagi masalah pembangunan di wilayah Desa Deleman Kedumgdung Sampang di masa sekarang dan masa mendatang. 5) Manfaat yang bisa diambil dari kegiatan ini adalah memberikan pengalaman belajar kepada civitas untuk turut serta membantu pelaksanaan dan pemecahan masalah dalam pembangunan wilayah Desa Deleman Kedumgdung Sampang. Selain itu juga melatih mahasiswa menjadi motivator 
dinamisator dalam penggerakan pembangunan dalam masyarakat. 6) Bagi masyarakat bermanfaat memperoleh bantuan pemikiran, tenaga, ilmu pengetahuan dan teknologi dalam pembangunan. Selain itu, masyarakat juga mendapat cara baru yang dibutuhkan untuk merumuskan dan memecahkan masalah-masalah yang ada. 7) Masyarakat menjadi lebih mandiri.

Selaku peserta PKM daring Institut Agama Islam Nazhatut Thullab tentu mulai merancang semua kegiatan yang sesuai dengan pashion juga sesuai dengan prodi yang sudah dijalankan selama 6 semester, apalagi dengan adanya ruang lingkup yang sudah ditentukan oleh panitia PKM IAI Nazhatut Thullab yang membuat kami merasa perlu untuk memberikan sebuah inovasi yang menjadi harapan besar dalam terlaksananya PKM tahun akademik 2019 - 2020 ini.

\section{METODE PENGABDIAN}

1. Persiapan; Tim pengabdian yang terdiri dari dosen dan mahasiswa IAI Nazhatut Thullab Sampang mempersiapkan kegiatan yang akan dilakukan selama pengabdian.

2. Sosialisasi; Tim pengabdian masyarakat menjelaskan tentang berbagai kegiatan yang akan dilakukan, termasuk berkaitan dengan mekanisme pelaksanaan kegiatan pengabdian.

3. Pendampingan; dalam kegiatan ini kami mendampingi anak-anak dan remaja secara langsung, untuk mencapai tujuan kegiatan pengabdian, yang salah satunya membantu memberdayakan masyarakat secara umum.

\section{HASIL DAN PEMBAHASAN}

\section{Kondisi Objek Pengabdian}

a. Letak objek pengabdian

Dusun Bates merupakan dusun yang terletak di Desa Daleman Kecamatan Kedungdung Kabupaten Sampang yang dipimpin oleh kepala dusun An. Karman. Dusun Bates merupakan dusun yang paling besar yang berada di Desa Daleman dan merupakan dusun yang paling padat penduduk. 
Dusun Bates terdiri dari beberapa kampung diantaranya adalah kampung Ghedding, Kacangan, Telaga, Gedangan warung Laok, Ebre, dan Betes. Dusun Bates juga merupakan dusun yang memiliki SDM lebih banyak dari pada dusun lain yang berada di Desa Daleman, dusun Bates terdiri dari masyarakat yang lebih mengutamakan kekompakan dan kesetaraan baik dalam segi kehidupan, sosial dan pendidikan.

Kegiata kemasyarakatan sangat dijaga oleh masyarakat dusun Bates tersebut sehingga percekcokan jarang ditemukan antar masyarakat dusun Bates kecuali perselisihan atas dasar kesalah pahaman antar keluarga dan sesama saudara. Masyarakat dusun Bates juga dikenal sebagai masyarakat yang memiliki pengaruh besar terhadap Desa Daleman karena posisi Kepala Desa saat ini berada di dusun Bates tepatnya di kampung Ghedding sehingga masyarakat dusun Bates bisa lebih dekat secara emosional dengan kepala Desa.

b. Letak perbatasan

Dusun Bates merupakan Dusun yang berada disetiap perbatasan dusun lain yang berada di Desa Daleman Dusun Bates merupakan dusun yang berada pertengahan desa Daleman, dusun Bates berada disebelah timur dusun Kloykoy, disebelah selatan dusun Kacodur dan disebelah utara dusun Laeran. c. Jumlah Penduduk

Sebagaimana yang sudah disebutkan diatas bahwa dusun Bates merupakan desa yang terdiri dari masyarakat terbanyak yang berada di Desa Daleman yang terdiri dari kurang lebih 5000 penduduk, oleh karenanya sesuai presentase yang kami dapat dari sekretaris desa dan kaur bidang sosial desa masyarakat yang berada di dusun Bates merupakan 37\% dari 100\% masyarakat yang berada di Desa Daleman, yang diperkirakan terdiri dari kurang lebih 1700 penduduk.

d. Klasifikasi Jumlah Berdasarkan Jenis Kelamin

Dari banyaknya penduduk yang berada di dusun Bates ini dapat kami klasifikasikan berdasarkan jenis kelamin yang sudah disesuaikan dengan data 
yang diperoleh langsung dari desa setempat yaitu terdiri dari 973 lak-laki dan 727 perempuan dengan catatan sebagai berikut: 1) $1-10$ tahun = 274; 2) 11 20 tahun $=467$; 3) $21-40$ tahun $=680$; dan 4) 41 - lansia $=279$ jiwa/orang.

e. Kondisi Ekonomi

Dengan banyaknya SDM di dusun Bates sangat memberi pengaruh besar terhadap perkembangan ekonomi asyarakat sehingga lambat laun masyrakat dusun Bates mampu berinovasi dengan baik dalam hal ekonomi sehingga tidak banyak penduduk yang hijrah ke kota lain dalam negeri ataupun hijrah keluar negeri. Sekalipun tak banyak penduduk yang memiliki jabatan pada umumnya namun secara mandiri penduduk mampu menjaga dan bahkan meningkatkan perekonomiannya dengan kemampuan yang dimilikinya seperti halnya menjadi pedagang pasir, meubel, buka toko dan bahkan memproduksi kerupuk yang dikenal dengan kerupuk rambak. Tidak hanya itu dengan kreatifitas semampunya penduduk dusun juga mampu mendapat penghasilan yang bisa mencukupi kebutuhan hidupnya seperti membuat pajangan seserahan manten, membuat kerenneng (wadah khusus rumput) dari bambu, dan membuat tali tambang dari rapia. Juga penduduk tidak mudah menyia nyiakan hasil bumi, seperti singkong yang dijadikan olen-olen (salah satu jajanan pasar), kacang yang dijadikan ancang dan tegetteh, dan lain sebagainya.

\section{f. Kondisi Pendidikan}

Bicara soal pendidikan di dusun Bates bisa dikatakan penuh dengan pendidikan, seperti seringnya diadakan majelis taklim disetiap acara selametan. Selain itu di dusun Bates merupakan dusun yang terdapat didalamnya banyak lembaga pendidikan ada SDN 1 Daleman, MI dan SMP Ar Roudloh Litahfidhil Qur'an dan MI, MTs dan MA Miftahut Thullab. Tidak hanya itu didusun Bates terdapat 6 kampung yang masing - masing kampung diadakan TPQ yang didirikan langsung oleh penduduk sekitar dan dipasrahkan secara penuh kepada seorang yang diketahui lulusan pondok pesantren, sehingga di setiap TPQ tidak hany difokuskan pada pelatihan atau penguatan 
baca dan tulis al Qur'an melainkan juga diisi dengan penjelasan ubudiyah dengan menggunakan kitab fikih syafi'iyah seperti Fiqh al Wadli dan lainnya.

g. Kondisi Agama

Dusun Bates merupakan dusun yang paling kental dalam urusan agama, hal itu juga dipengaruhi oleh besarnya SDM yang ada di dusun tersebut, sehingga tak banyak ditemukan orang jahat (bejing) atau atau kenakalan remaja, agama sangat diprioritaskan oleh penduduk dusun karena disana terdapat banyak tokoh sentral yang aktif bahkan menjabat sebagai pengurus organisasi keagamaan Nahdlotul Ulama'. Dengan kekentalan agama di dusun tersebut menyebabkan terbentuknya kegiatan keagamaan disetiap kampung yang berada didusun tersebut seperti yasinan setiap malam jum'at, sholawatan setiap malam selasa, majlis taklim sebagai haul sesepuh sebulan sekali setiap tanggal 11 bulan hijriyah. Kondisi agama didusun tersebut sangat luar bisa bahkan semua penduduk mgajarkan anak - anaknya untuk senantiasa berkopyah saat keluar jauh dari rumah, bahkan sesuai fakta yang kami dapat, penduduk lebih memilih membelikan anaknya sarung baru saat ada acara besar, seperti mantenan dan lain sebagainya, dengan alasan agar lebih islami dan tidak bergaya berandal yang identik dengan pakaian serba gaul seperti celana pendek, celana jeans dan model baru yang sobek - sobek.

Tidak hanya itu penduduk lebih juga lebih memilih mengundan grup hadroh al banjari sebagai hiburan dalam acara kekeluargaan dari pada gambus milenial ataupun orkes musik dan lainnya, dengan alasan agar semua hal yang dilakukan bisa mendapat ridlo ilahi dengan banyaknya bacaan sholawat yang ditampilkan oleh grup hadroh al banjari tersebut. Apalagi dalam acara manten yang merupakan sunnah Rasul, dengan berdasarkan sejarah perang badr dimana nabi Muhammad disambut dengan pembacaan shalawat badr saat kembali membawa kemenangan diperang tersebut.

h. Kondisi Sosial Budaya

Bicara soal adat dan budaya penduduk dusun sangat bersemangat untuk senantiasa melestarikan adat dan budaya leluhurnya, dengan tetap 
menjalankan amanat leluhur yang dirasa baik dan berada dilingkup agama yang dianutnya. Tidak bisa dipungkiri sesuai fakta penduduk tidak pernah tahu maksud dan tujuan dari adanya adat dan budaya tersebut, hanya saja penduduk merasa wajib untuk melestarikannya, seperti halnya rebbe setiap malam jum'at kliwon rokat buyut setiap setahun sekali.

Pada awalnya penduduk bertujuan untuk mendo'akan sanak saudara yang sudah wafat dengan berbagai jamuan yang sediakan oleh masing masing penduduk tanpa mengetahui pentingnya tawasul dan manfaat sedekah yang diberikan kepada orang lain, namun dengan keyakinan lambat laun mereka sadar akan besarnya manfaat dari apa yang dilakukan melalui majlis taklim yang sering digelar.

i. Sarana Peribadatan

Sarana peribadatan merupakan hal penting yang harus ada dan tersedia bagi setiap penduduk, sarana peribadatan sudah diposisikan di nomor dua setelah rumah untuk berteduh oleh penduduk dusun Bates. Semua penduduk rata - rata lebih memilih membangun surau dari pada harus membangun atau merevisi rumah. Karena menurut penduduk memperindah tempat beribadah itu lebih utama dari pada memperindah rumah yang hanya digunakan untuk tidur dan kemungkinan dijadikan tempat berbuat dosa, seperti menggunjing dan membicarakan kejelekan sesama tetangga sekitar. Tidak hanya itu, merasa wajib untuk membangun surau bukan karena untuk hal vertikal melainkan juga untuk hal yang sifatnya horizontal, seperti menerima tamu besar, atau tamu tetangga dengan alasan supaya lebih afdol dan tidak terganggu dengan kebisingan keluarga. ${ }^{2}$

\section{Pelaksanaan kegiantan pengabdian}

a. Sosialisai pencegahan penularan COVID 19

Melihat banyaknya penduduk yang tidak percaya adanya virus yang sangat berbahaya ini dan dengan tuntutan yang diwajibkan panitia terkait kewajiban adanya kegiatan sosialisasi sederhana mengenai pencegahan

\footnotetext{
2 Dokumen Desa Daleman Dusun Bates Kecamatan Kedungdung Sampang 2019/2020.
} 
penularan covid 19 ini kami mengharap penduduk sadar akan bahaya virus tersebut, dan penduduk bisa mulai antisipasi untuk menghindar dari penularan virus tersebut. Selain itu kami harap pihak desa ataupun tokoh didusun ini bisa lebih mudah untuk mengajak penduduk lebih meningkatkan imunitas tubuh dan lebih menjaga kesehatan dengan tidak seenaknya menyentuh sesuatu yang tidak kita sadari mengandung bakteri dan virus yang sangat berbahaya.

b. Penguatan baca tulis al-Qur'an

Sebagai mana kami jelaskan pada point B bahwa dusun Bates merupakan dusun yang disetiap kampungnya terdapat TPQ yang dipasrahkan kepada salah satu penduduk yang diketahui lulusan pondok pesantren. Namun demikian semua pemangku TPQ rata - rata sudah berumur sekitar 30 - 40 tahun sehingga kami menilai sudah tidak banyak metode yang bisa diterapkan dalam meningkatkan kualitas baca tulis al-Qur'an, sesuai fakta yang ada banyak beberapa musholla hanya memakai metode sorogan dengan membenarkan kesalahan dalam pembacaan dan penulisan tidak disertakan cara ataupun perbedaannya.

Oleh karena itu harapan besar kami selaku peserta PKM semoga dengan dampingan yang kami lakukan dapat memberikan inovasi baru bagi musholla yang menjadi objek kami selama PKM berlangsung, dan semoga dengan adanya dampingan yang kami lakukan bisa ditindak lanjuti oleh pemilik TPQ hingga dapat melahirkan lulusan yang mampu membaca dan menulis ayat alQur'an dengan baik sesuai aturan baca dan tulis al-Qur'an yang sudah ditentukan. 

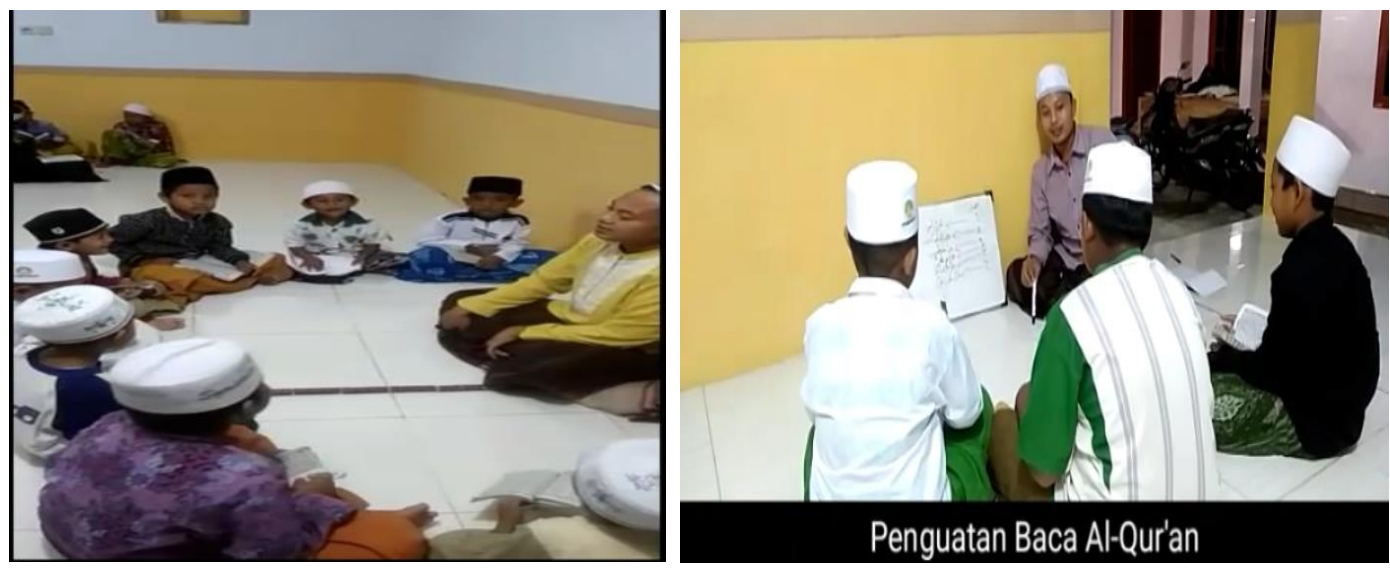

Gambar 1: Pembinaan baca al-Quran anak-anak dan remaja

c. Pembinaan ibadah

Beribadah merupakan suatu bukti pengabdian seseorang kepada sang pencipta dengan melaksanakan amalan yang diperintahkan sesuai dengan penjelasan sumber Islam yaitu al-Qur'an dan Hadis. Pembiasaan beribadah harus dimulai sejak usia dini pada anak, agar agama yang mereka anut bisa melekat dalam dirinya dan memiliki pondasi atau perisai agar dapat membentengi diri untuk melewati berbagai tantangan yang jelas bisa merusak jati diri sebagai orang yang beragama. Salah satu cara dalam meningkatkan pengalaman keberagamaan pada siswa adalah dengan membina siswa dalam melaksanakan ibadah yang bentuk pelaksanaannya tampak yaitu salat. Oleh karena itu, diperlukan berbagai macam strategi membina siswa dalam beribadah untuk mengatasi masalah yang menjadikan siswa malas mengamalkan ibadah dalam agama.

Ibadah merupakan manifestasi ketundukan seoarang hamba yang merasa rendah, hina, dan lemah di hadapan Sang Maha Kuasa, yaitu Allah swt. Pada dasarnya, ibadah merupakan pemenuhan karakter dasar manusia yang secara fitrah mengakui adanya eksistensi di luar dirinya yang mempunyai kekuasaan yang 12 Agung, hal ini dibuktikan dengan penemuan-penemuan sejarah nenek moyang kita yang memiliki kepercayaan animisme dan dinamisme, yaitu kepercayaan kepada roh-roh leluhur dan bendabenda yang dianggap mempunyai kekuatan serta dapat memberikan pertolongan serta 
perlindungan. Perilaku nenek moyang tersebut merupakan naluri fitrah, karena pada dasarnya manusia diciptakan untuk beribadah.

Pembinaan dalam melaksanakan salat dapat dilakukan dengan cara marhalatuzhzharbi wa ta'dib wat targhib (memukul, mendidik, menakutnakuti) fase ini sejak umur sepuluh tahun sampai dewasa. Sebagai bahan perbandingan, dalam masalah salat Nabi saw. Beliau memerintahkan agar menyuruh anak untuk mengerjakan salat saat berumur tujuh tahun dan memerintahkan memukul saat mereka berumur sepuluh tahun. ${ }^{3}$

Tidak dapat diragukan lagi bahwa penduduk dusun Bates mayoritas sangat menjaga semangtatnya dalam urusan ibadah, baik yang kecil, remaja, dewasa bahkan oratua dan lansia, setiap keluarga saking bahu membahu untuk meningkatnya rasa cinta untuk beribadah, namun demikian tak banyak juga penduduk yang hanya menganggap ibadah sebagai kewajiban dan syarat sahnya kewajiban tanpa tahu keutamaan juga hal lain yang bisa lebih menyempurnakan ibadahnya. Apalagi orang tua ataupu lansia yang tidak lagi menghiraukan kebersiahan badan, pakaian dan tempat, penduduk yang sudah lanjut usia hanya tahu bahwa ia tidak pernah menyentuh najis atau yg melekat pada badannya tidak berbau najis.

Dengan ini kami memberikan pembinaan ibadah dengan menjadikan penduduk yang dinilai membutuhkan untuk meningkatkat kualitas ibadah sesuai yang dianjurkan, dengan harapan semoga penduduk dusun lebih menjaga ibadah dan hal-hal yang berhubungan dengan kesempurnaan ibadahnya, lebih mengukur waktu ibadah saat bekerja mencari nafkah dan menyadarkan penduduk bahwa ibadah merupakan kunci utama suksesnya semua pekerjaan.

${ }^{3}$ http://repository.iainpalopo.ac.id/id/eprint/1367/1/Darmawati.pdf, diakses pada tanggal 4 April 2021 

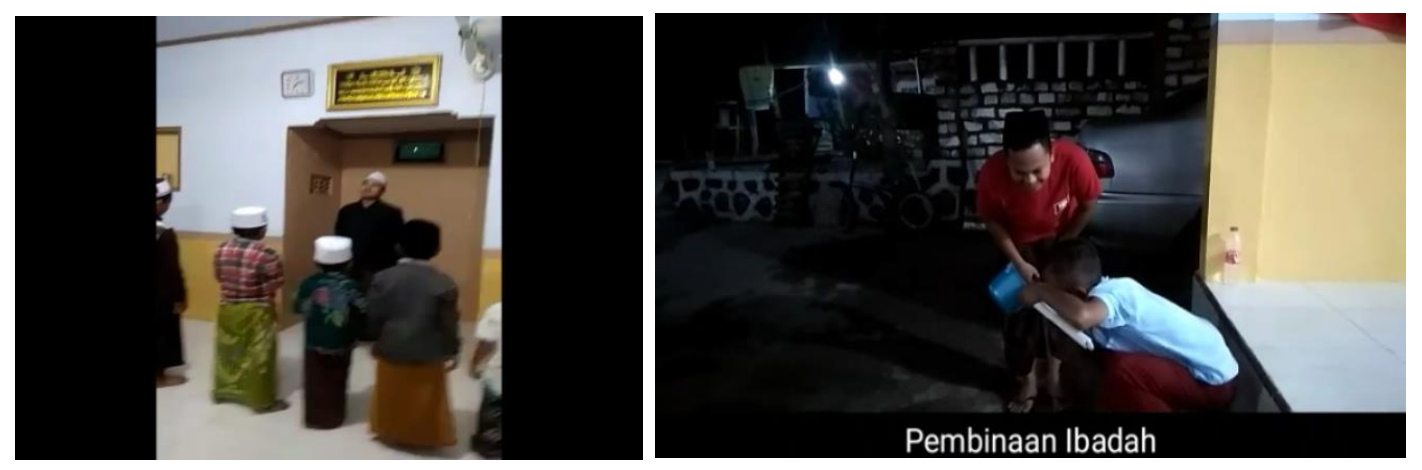

Gambar 2: Pembinaan Ibadah

d. Pembinaan moral/akhlak

Dasar pembinaan akhlak yang menjadi ukuran baik dan buruk atau mulia dan tercela, semata-mata karena syara' sebagaimana keseluruhan ajaran islam,oleh karena itu dasar pembinaan akhlak tidak terlepas dari Al-Quran dan Al-Hadits yang memberi pandangan dan mengacu kepada kehidupan dunia ini, maka dasarnya harus memberi kepada pendidikan islam. Islam menganjurkan kepada manusia untuk selalu berpikir positif dan mencontohi perilaku Rasulullah Saw, karena dalam diri beliau terdapat suri teladan yang baik, dasar akhlak islam berdasarkan Al-Qur'an. ${ }^{4}$

Setelah beberapa hari kami melakukan analisis pembinaan akhlak perlu diterapkan didusun bates, karena ditemukan pemuda yang sering ditemukan bolos sekolah pergaulannya juga tidak ada yang membatasi, sehingga pemuda tersebut tidak sedikitpun merasa canggung berkumpul dengan siapa saja, baik dengan orang yang lebih tua apalagi dengan yang lebih muda. Hal tersebut mengakibatkan menurunnya akhlak karena dengan seringnya terjadi perkumpulan pemuda tersebut menganggap semuanya teman biasa tanpa harus menghormati secara lebih.

Dengan demikian kami melaksanakan pembinaan pada anak usia dini dan remaja yang belum terjerumus pada pergaulan bebas, dengan harapan anak dan remaja tersebut mampu membedakan mana yang perlu disayangi dan mana yang harus dihormati. Tidak hanya itu kami juga memberikan

${ }^{4}$ https://digilibadmin.unismuh.ac.id/upload/9049-Full Text.pdf, diakses pada tanggal 4 April 2021 
bimbingan bagaimana cara kita duduk saat berkumpul dengan orang banyak, harapan besar dari hal tersebut semoga anak dan remaja tersebut bisa menjadi anak atau remaja yang sesuai dengan yang dijelaskan dalam kitab Bidayah al Hidayah, yaitu tentang menyayangi yang lebih muda dan menghormati yangg lebih tua, baik lebih tua ilmunya maupun umurnya.
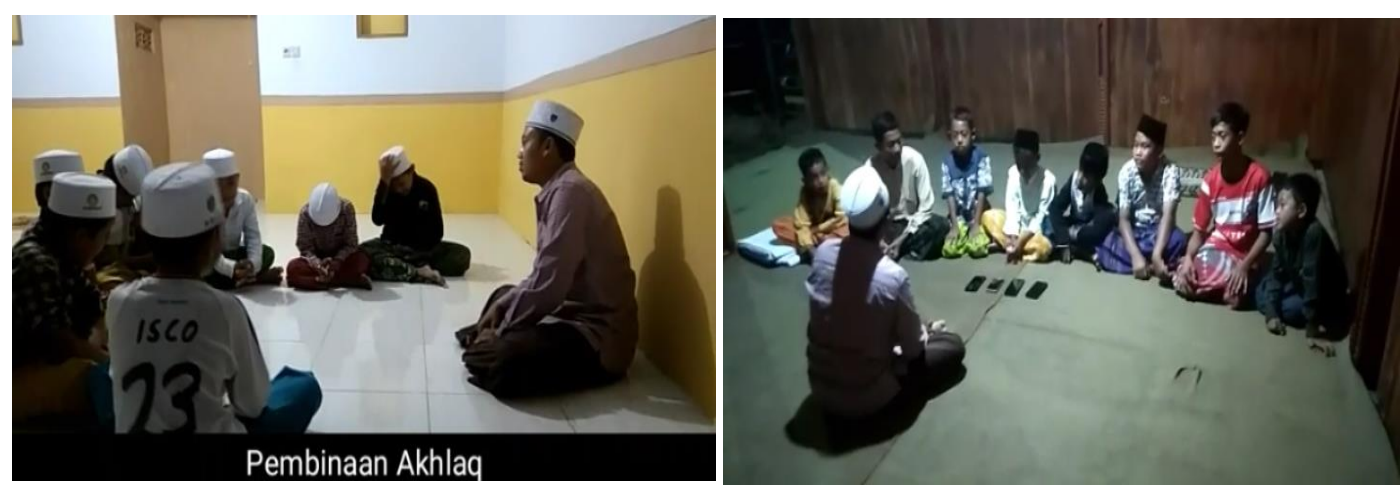

Gambar 3: Pembinaan moral/akhlak anak-anak dan remaja

Berikut tabel hasil kegiatan pengabdian kepada masyarakat.

\begin{tabular}{|c|l|l|l|}
\hline No & \multicolumn{1}{|c|}{ Jenis kegiatan } & \multicolumn{1}{|c|}{ Sasaran } & \multicolumn{1}{|c|}{ Lokasi } \\
\hline 1 & $\begin{array}{l}\text { Sosialisasi } \\
\text { pencegahan } \\
\text { penularan covid 19 }\end{array}$ & $\begin{array}{l}\text { Karang Taruna, } \\
\text { anak usia dini } \\
\text { dan lembaga }\end{array}$ & $\begin{array}{l}\text { Sekretariat Karang } \\
\text { Taruna, musholla dan } \\
\text { lembaga }\end{array}$ \\
\hline 2 & $\begin{array}{l}\text { Penguatan baca } \\
\text { tulis al Qur'an }\end{array}$ & Anak usia dini & $\begin{array}{l}\text { Musholla As Saadah dan } \\
\text { Musholla Al Hidayah }\end{array}$ \\
\hline 3 & Pembinaan ibadah & $\begin{array}{l}\text { Anak usia dini } \\
\text { dan masyarakat } \\
\text { sekitar }\end{array}$ & $\begin{array}{l}\text { Musholla dan rumah } \\
\text { penduduk }\end{array}$ \\
\hline 5 & $\begin{array}{l}\text { Gerakan } \\
\text { masjid/musholla } \\
\text { bersih }\end{array}$ & $\begin{array}{l}\text { Anak usia dini } \\
\text { dan remaja }\end{array}$ & Musholla As Saadah \\
\hline 5 & Pembinaan akhlak & $\begin{array}{l}\text { Anak usia dini, } \\
\text { remaja dan } \\
\text { dewasa }\end{array}$ & $\begin{array}{l}\text { Rumah penduduk, } \\
\text { musholla dan tempat } \\
\text { perkumpulan orang } \\
\text { banyak (gardu dan surau) }\end{array}$ \\
\hline
\end{tabular}

\section{KESIMPULAN}

Dari apa yang telah peneliti paparkan, bisa diambil benang merahnya bahwa masyarakat yang ada di dusun Bates masih mengalami problematika atau 
permasalahan yang harus diselesaikan oleh elemen-elemen masyarakat itu sendiri sehingga mampu meminimalisir permasalahan yang ada. Kehadiran mahasiswa peserta PKM IAI NATA paling tidak bisa memberikan sumbangsih pemikiran, tenaga, dan lainnya dalam mengatasi permasalahan yang ada bersama masyarakat, sesuai tri dharma perguruan tinggi dimana mahasiswa dianjurkan menjadi abdi bagi masyarakat untuk menyelesaikan problematka yang ada yaitu dengan melakukan diskusi bersama masyrakat untuk menemukan permaslahan yang ada, setelah permaslahan ditemukan maka langkah selanjutnya mencari solusi dan memberi dampingan bagi masyrakat untuk menyelesaikannya.

Program yang dilaksanakan oleh peserta PKM dan masyarakat yaitu program yang berhubungan dengan problematika yang ditemukan oleh kami sebagai peserta PKM diantaranya, pembinaan akhlak, pembinaan ibadah, sosialisai pencegahan COVID 19, penguatan baca tulis al-Qur'an dan gerakan masjid/musholla bersih.

\section{DAFTAR PUSTAKA}

Sudin, Kuliah Pengabdian Masyarakat Perguruan Tinggi Islam,journal of UIN Sunan Kalijaga diakses tanggal 21 Juli 2020.

Dokumen Desa Daleman Dusun Bates Kecamatan Kedungdung Sampang $2019 / 2020$.

http://repository.iainpalopo.ac.id/id/eprint/1367/1/Darmawati.pdf, diakses pada tanggal 4 April 2021

https://digilibadmin.unismuh.ac.id/upload/9049-Full Text.pdf, diakses pada tanggal 4 April 2021 